\title{
On the connection between terrestrial and riparian vegetation: the role of storage partitioning in water-limited catchments
}

Saúl Arciniega-Esparzaํ, José Agustín Breña-Naranjo', Peter A. Troch²,3

\begin{abstract}
1'Instituto de Ingeniería, Universidad Nacional Autónoma de México, Mexico 2Department of Hydrology and Water Resources, University of Arizona, USA

${ }^{3}$ Biosphere 2 Earthscience, University of Arizona, USA
\end{abstract}

Corresponding author and address: Jose Agustin Breña-Naranjo, Instituto de Ingeniería, UNAM, Mexico City, Mexico email: jbrenan@ii.unam.mx 


\section{Ecosystem functioning and annual water balance}

Understanding how ecosystem functioning affects hydrological partitioning at the catchment scale is critically important to predict the annual water balance under climate-related land use change. Terrestrial ecosystems rely on rainfall infiltration while riparian ecosystems rely on the accumulation of surface and subsurface runoff in the riparian zone and the channel network. Some of the rainfall that infiltrates into the soils will be available for plants on the catchment's hillslopes. Some of that water may percolate down the soil profile where it can recharge a perched shallow aquifer or move even deeper to recharge bedrock aquifers. Lateral shallow subsurface flow provides a subsidy of water to plants downslope, which allows different plant species to occupy the toeslopes (Thompson et al., 2011a; Hwang et al., 2012). Perched and deep aquifers can sustain streamflow during dry periods and are thus essential for riparian and aquatic ecosystems. At the catchment scale, the persistence of flow can be analyzed by means of the flow duration curve (a plot that shows the percentage of time that discharge in a stream is likely to equal or exceed some specified value of interest).

Climate has a first order control on the annual water balance (Budyko, 1974). The aridity index (ratio of average annual potential evapotranspiration, PET, to average annual rainfall, $\mathrm{P}$ ) can predict the evaporative fraction and the runoff coefficient at climate time scales ( $\sim 30$ years) in many catchments. Less is known about how catchment ecosystems affect the annual water balance. Huxman et al. (2004) showed that when biomes undergo drought conditions their rainwater use efficiency (Net Primary Production/P) converges to a common maximum value. In a similar context, Troch et al. (2009) introduced the Horton index (the ratio of vaporization (i.e. evapotranspiration) to catchment wetting (the amount of water that infiltrates into the soils and does not runoff superficially) as a measure of rainwater use efficiency of the catchment's ecosystems, and showed that the Horton Index (HI) converges to a value of 1 when catchments undergo drought conditions. Subsequent research about the HI found that the index is controlled by climate (aridity index) and landscape characteristics (catchment slope and elevation) and is a useful first-order predictor for annual and interannual vegetation greenness at the catchment scale (Brooks et al., 2011; Voepel et al., 2011). 
The role of catchment water storage on vegetation response has been acknowledged in several recent ecohydrological studies (Tague, 2009; Miller et al., 2010; Thompson et al., 2011a). Evidence that water storage subsidizes plant water use through lateral hydrological connectivity (driven by topography) has been shown at the plot and the catchment scale and across different biomes (Scott et al., 2008; Thompson et al., 2011b; Hwang et al., 2012). Past research carried out in a temperate climate experimental watershed suggests a direct relationship between landscape position and storage that enhances local vegetation development (Hwang et al., 2009). More recently, Gao et al. (2014) showed that ecosystems dynamically design their root systems to bridge droughts with return periods of 10-40 years, where root storage capacity (largely controlled by its depth) is likely to be more prominent as climate becomes drier.

This commentary focuses on the following questions: How much water that infiltrates (and is subsequently stored) into the soils do plants use in water-limited regions (aridity index $>1$ )? And how much of that water becomes streamflow during dry periods and thus sustains riparian and aquatic ecosystems? We address these questions (Section 2) by computing for 33 semi-arid catchments in Mexico the annual maximum total storage $\left(S_{t}\right)$ using a daily water balance approach (Sayama et al., 2011), and inferring the annual maximum deep storage $\left(S_{d}\right)$ using a baseflow separation approach. We then investigate under what conditions these two types of storage are related, and what explains their spatial variability in these 33 catchments in Mexico (Sections 3 and 4). Finally, we draw conclusions as to how terrestrial and riparian ecosystems are connected at the catchment scale.

\section{The relationship between total \& deep storage at the catchment scale}

Catchment water storage is driven by multiple physical and biological processes and its separation into shallow and deep components controls the catchment's hydrological response (e.g. evapotranspiration is controlled by soil moisture, while baseflow is controlled by deep storage). In water-limited regions (where $\mathrm{PET} / \mathrm{P}>1)$, catchment vaporization $(\mathrm{V}$, an alternative term for evapotranspiration) is very close to available wetting (W) because plants will use the maximum available water stored in the soil. It is thus expected that 
very little deep storage will exist in dryland catchments. It is unknown, however, how climate and landscape mediate the partitioning between shallow and deep storage in these catchments, and how this partitioning affects vegetation patterns (see Figure 1).

Here we analyze the spatio-temporal dynamics of annual maximum total storage $\left(\mathrm{S}_{t}\right)$ and deep storage $\left(\mathrm{S}_{\mathrm{d}}\right)$ in 33 catchments located in water-limited environments (PET/P>1) across Mexico (Figure 2, left panel). The region of study features strong hydro-climatic gradients, as shown in the long-term precipitation, vaporization and aridity index distribution (Figure 2, right panel). In addition, some landscape properties such as mean catchment elevation, slope, permeability and porosity indicate a wide range of topographic and geologic settings that can further influence storage dynamics (Sayama et al., 2011).

The study catchments are located in semi-arid and arid climates across the northern, central and southern regions of Mexico (Figure 2). These regions are divided into three main geographical zones: the Sierra Madre Occidental west of the Chihuahuan desert, the Sierra Madre del Sur along the southern states of Guerrero and Oaxaca and the Altiplano in northern-central Mexico. The surface hydrology of the region is characterized by intermittent streamflow regimes in small and mid-size catchments during the dry season (November to April) in the Altiplano and Sierra Madre del Sur. In catchments located in the Sierra Madre Occidental, the North American summer monsoon dominates annual streamflow (Bohn and Vivoni, 2016).

Drainage areas vary between 100 and $23000 \mathrm{~km}^{2}$, though most catchments fall in the range of 1,000 and 10,000 $\mathrm{km}^{2}$ (Figure 2). Several of these catchments are located along middle-upper elevations ranging from 1,600 and 2,400 masl, with average slopes between 15 and 30\% (the steeper catchments are found across the Sierra Madre Occidental and Sierra Madre del Sur). We selected catchments that have daily streamflow records of at least 20 years between 1950 and 2013 and without dams upstream of the gauging stations. The main climate and landscape properties of these watersheds are provided as Supplementary Material (Table S1).

The temporal dynamics of total catchment storage at the daily scale were analysed using the catchment water balance equation: 
$\mathrm{S}_{\mathrm{t}}(\mathrm{t})=\sum(\mathrm{P}(\mathrm{t})-\mathrm{Q}(\mathrm{t})-\mathrm{V}(\mathrm{t})) \Delta \mathrm{t}$

where $\mathrm{S}_{\mathrm{t}}(\mathrm{t})$ is the cumulative catchment total storage at day $\mathrm{t}$, and $\mathrm{P}(\mathrm{t}), \mathrm{Q}(\mathrm{t})$ and $\mathrm{V}(\mathrm{t})$ are daily precipitation, streamflow and vaporization, respectively. $\Delta t$ is the time step (in this case, one day). Daily estimates of $S_{t}(t)$ are computed from the start of the rainy season in May (assuming $\left.S_{t}(0)=0\right)$ until the end of the dry season in April of the following year. The maximum daily $S_{t}(i)$ value for every year $i$ was selected as a proxy of the annual maximum total storage at the catchment scale (Figure 3, top).

The temporal dynamics of $S_{d}$ were obtained from daily baseflow time series that were computed by baseflow separation using a digital recursive filter [Ajami et al., 2011; Beck et al., 2013]. For this study, an optimal value of 0.925 for the filter parameter was considered [Natahan and McMahon, 1990]. $S_{d}$ was computed assuming a linear storage relationship between annual maximum baseflow, $\mathrm{U}_{\max }$ and annual maximum deep storage, $\mathrm{S}_{\mathrm{d}}\left(\mathrm{S}_{\mathrm{d}}=\mathrm{KU}_{\mathrm{max}}\right)$, where $\mathrm{K}$ is a storage constant (days). $\mathrm{K}$ was derived from baseflow recession analysis [Brutsaert and Nieber, 1977] (Figure 3, bottom).

Time series of $S_{t}$ and $S_{d}$ were averaged per catchment to derive the average maximum total storage, $\overline{S_{t}}$, and deep storage, $\bar{S}_{d}$. Our estimates of average maximum total storage and average maximum deep storage are based on different data sets, and it is thus unknown to what extent $\overline{S_{t}}$ and $\bar{S}_{d}$ are related. Average maximum total storage $\left(\overline{S_{t}}\right)$ depends on the balance between inputs and outputs at the catchment scale, whereas average maximum deep storage $\left(\overline{S_{d}}\right)$ depends on baseflow conditions in response to groundwater dynamics and effective recharge. Under these conditions, it is expected that catchment-scale precipitation, wetting and evapotranspiration control the temporal dynamics of $S_{t}(i)$ and $S_{d}(i)$ at the inter-annual scale.

The correlation between $\mathrm{S}_{t}(\mathrm{i})$ and $\mathrm{S}_{d}(\mathrm{i})$ of all 33 catchments is shown in Figure 4 . The long-term Pearson correlation coefficient $(\mathrm{R})$ is mainly positive, with the exception of one catchment. In catchments with statistically significant positive correlation coefficients (large red circles; $\mathrm{p}<0.01$ ), the interannual variability of total and deep storage is in synch (an example is shown in Figure 4). On the other hand, in catchments with low correlation coefficients (small red circles), deep storage is disconnected from total storage (Figure 
4). There is one catchment (see blue circle in the map and inset plot at the bottom) with a negative (and statistically non-significant, $\mathrm{p}=0.30$ ) $\mathrm{R}$ value. Although this catchment is an exception (and possibly an outlier), this observed pattern could be explained by intensive groundwater abstractions. Overall, most of the analysed catchments ( 24 out of 33 , see Table S1) have a medium-to-high correlation coefficient $(\mathrm{R}>0.50)$ that is statistical significant $(\mathrm{p}<0.05)$.

Our results show that $\mathrm{S}_{\mathrm{t}}(\mathrm{i})$ is on average an order of magnitude larger than $\mathrm{S}_{\mathrm{d}}(\mathrm{i})$ (177 $\mathrm{mm}$ vs. $\left.22 \mathrm{~mm}\right)$. The difference is even more pronounced when their median values are compared (140 mm vs. $9 \mathrm{~mm})$. In addition, the interannual variability of $S_{t}$ and $S_{d}$ (coefficient of variation of 91 and 33, respectively) shows that deep storage is more sensitive to natural climate forcing variability.

\section{Controls of total and deep storage at the catchment scale}

The second part of this study explores the climate variables and landscape parameters that potentially control the average maximum $\overline{S_{t}}$ and $\overline{S_{d}}$. As shown in Figure 5a, average catchment wetting (W, the amount of precipitation not contributing to surface runoff, see (Horton, 1933; Troch et al., 2009) for further details) explains most of the spatial variability in $\overline{S_{t}}(\mathrm{R}=0.91)$. Other catchment-scale variables that are highly correlated with $\overline{S_{t}}$ are average vaporization (V; Figure $5 \mathrm{~b}, \mathrm{R}=0.83$ ), and to a lesser degree mean catchment slope $(\mathrm{R}=0.59)$ and aridity index $(\mathrm{R}=0.50)$ (not shown). The relationship between mean slope and $\bar{S}_{t}$ confirms the results of Sayama et al. [2011]. These authors studied steep, first-order watersheds located in a forested and temperate region (with climate, vegetation and landscape characteristics quite different from our study sites), so our findings provide further evidence about the dominant role of topography on $\overline{S_{t}}$. Based on these results, we examined the role of the Horton index $(\mathrm{HI})$ as it is given that $\mathrm{HI}$ is defined by the ratio of $\mathrm{W}$ and V, but is also strongly related to aridity index and catchment slope [Voepel et al., 2011]. Surprisingly, such relationship seems to be moderately weak (Figure 5c). 
On the other hand, the average maximum deep storage $\left(\overline{S_{d}}\right)$ is strongly controlled by the Horton Index $(\mathrm{R}=$ -0.91) (Figure 5i), followed by $\mathrm{W}(\mathrm{R}=0.52$, Figure $5 \mathrm{~g})$, slope $(\mathrm{R}=0.52)$ and $\mathrm{AI}(\mathrm{R}=0.48)$. Surprisingly, the water balance components that define the $\mathrm{HI}(\mathrm{V}$ and $\mathrm{W})$ seem to be less efficient predictors of $\overline{S_{d}}$.

The robust controls of the Horton Index on $\overline{S_{d}}$ may help to anticipate the long-term hydrological response in water-limited catchments, represented here as flow duration curves (Figure 6). Semi-arid regions with HI values (and moderate water use efficiency) between 0.65 and 0.85 (blue and yellow lines) are characterized by perennial streamflow regimes during most of the year, but catchments with values above 0.85 (orange and red lines) indicate high water use efficiency and intermittent river flows.

\section{The connection between terrestrial and riparian vegetation in dryland catchments}

Vegetation patterns at the catchment scale indicate the amount of available water that sustains evapotranspiration. In absolute terms, evapotranspiration from terrestrial ecosystems dominates catchment vaporization and is controlled by catchment wetting (Figure 5a and 5b). The fraction of wetting not utilized by terrestrial vegetation (i.e. 1 - HI) controls average deep storage in catchments (Figure 5f), as expressed in the catchments' flow duration curves (Figure 6). There thus seems to be a strong connection between terrestrial and riparian vegetation in these semi-arid catchments. When the terrestrial ecosystems are very efficient in their rainwater use $(\mathrm{HI} \sim 1)$, there is insufficient percolation down to deep storage to sustain lateral subsurface flow towards the drainage network. Riparian vegetation in these catchments relies entirely on surface runoff subsidy (Niu et al., 2014). In catchments with less efficient terrestrial vegetation in terms of rainwater use, sufficient water can enter deep storage to sustain flow during dry periods. This results in riparian vegetation that depends on lateral subsurface flow subsidy.

We investigated the relationship between terrestrial and riparian vegetation by analysing what controls average maximum total and deep storage across different catchments. From our analysis we learned that average catchment wetting controls average maximum total storage. This storage is primarily available to 
terrestrial vegetation, and average catchment vaporization is thus a response to the forcing provided by average catchment wetting. The ratio of vaporization and wetting $(\mathrm{HI})$ does not predict the spatial variability of average maximum total storage across semi-arid catchments in Mexico as efficiently as wetting. In contrast, the $\mathrm{HI}$ is an extremely efficient predictor of the spatial variability of average maximum deep storage in this region. This is also reflected by the fact that $\mathrm{HI}$ clearly determines the shape and relative position of the flow duration curves of these catchments. Such contrasting response of maximum total and deep storage to the Horton Index implies that catchment storage is both a cause and consequence of vegetation and its plant water use efficiency at the catchment scale.

The fact that deep storage dominates the hydrological response of catchments during dry periods is usually attributed to climatic, geomorphologic and landscape patterns [Wang and Wu, 2013; Beck et al., 2015]. Evidence that baseflow is explained by the Horton Index highlights the importance of vegetation and their feedbacks with catchment storage partitioning. However, this connection has often been overlooked in spite of previous findings suggesting an ecohydrological coevolution between subsurface flow and spatial vegetation distribution [Hwang et al., 2012].

These water balance dynamics connect terrestrial and riparian vegetation at the catchment scale in interesting (and previously unknown) ways. If these patterns hold for other regions and climates (either different geographic location of similar semi-arid catchments, or more humid catchments in the same region), simple water balance analysis can teach us a lot about the source of water for riparian vegetation, as well as the time and amount of water available for riparian and aquatic ecosystems. These are interesting results that need further research.

\section{Acknowledgements}

This work was funded by the "Predictability of hydrological response in dryland environments: a comparative study across North America" project, financially supported by the Consortium for Arizona- 
Mexico Arid Environments (CAZMEX) consortium between the University of Arizona and CONACYT. We thank Prof. Jim Buttle for his comments that improve the quality of the manuscript. 


\section{References}

Ajami H, Troch PA, Maddock T, Meixner T, Eastoe C. 2011. Quantifying mountain block recharge by means of catchment-scale storage-discharge relationships. Water Resources Research 47: 1-14. doi:10.1029/2010WR009598

Beck HE, Van Dijk AIJM, Miralles DG, De Jeu RaM, Bruijnzeel La, McVicar TR, Schellekens J. 2013. Global patterns in base flow index and recession based on streamflow observations from 3394 catchments. Water Resources Research 49: 7843-7863. doi:10.1002/2013WR013918

Beck HE, van Dijk AIJM, de Roo A. 2015. Global maps of streamflow characteristics based on observations from several thousand catchments. Journal of Hydrometeorolology 16(4): 1478-1501

Bohn TJ, Vivoni ER. 2016. Process-based characterization of evapotranspiration sources over the North American monsoon region. Water Resources Research 1-27. doi:10.1002/2015WR017934

Brooks PD, Troch PA, Durcik M, Gallo E, Schlegel M. 2011. Quantifying regional scale ecosystem response to changes in precipitation: Not all rain is created equal. Water Resources Research 47: W00J08, doi:10.1029/2010WR009762

Brutsaert W, Nieber JL. 1977. Regionalized drought flow hydrographs from a mature glaciated plateau. Water Resources Research doi:10.1029/WR013i003p00637

Budyko MI. 1974. Climate and Life, 508 pp. Academic, N. Y.

Gao H, Hrachowitz M, Schymanski SJ, Fenicia F, Sriwongsitanon N, Savenije HHG. 2014. Climate controls how ecosystems size the root zone storage capacity at catchment scale. Geophysical Research Letters 41: 79167923. doi:10.1002/2014GL061668

Horton RE. 1933. The role of infiltration in hydrologic cycle. Trans. Am. Geophys. Union 14, 446-460

Huxman TE, Smith MD, Fay PA, Knapp AK, Shaw MR, Loik ME, Smith SD, Tissue DT, Zak JC, Weltzin JF, Pockman WT, Sala OE, Haddad BM, Harte J, Koch GW, Schwinning S, Small EE, Williams DG. 2004. Convergence across biomes to a common rain-use efficiency. Nature 429: 651-654. DOI: 10.1038/nature02561

Hwang T, Band L, Hales TC. 2009. Ecosystem processes at the watershed scale: Extending optimality theory from plot to catchment. Water Resources Research 45: W11425, doi:10.1029/2009WR007775 
Hwang T, Band LE, Vose JM, Tague C. 2012. Ecosystem processes at the watershed scale: Hydrologic vegetation gradient as an indicator for lateral hydrologic connectivity of headwater catchments. Water Resources Research 48: W06514. doi:10.1029/2011WR011301

Miller GR, Chen X, Rubin Y, Ma S, Baldocchi DD. 2010. Groundwater uptake by woody vegetation in a semiarid oak savanna. Water Resources Research 46: W10503. doi:10.1029/2009WR008902

Natahan RJ, McMahon TA. 1990. Evaluation of automated techniques for baseflow and recession analyses. Water Resources Research 26: 1465-1473. doi:10.1029/90WR00136

Niu GY, Troch PA, Paniconi C, Scott RL, Durcik M, Zeng X, Huxman T, Goodrich D, Pelletier J. 2014. An integrated modelling framework of catchment-scale ecohydrological processes: 2 . The role of water subsidy by overland flow on vegetation dynamics in a semi-arid catchment. Ecohydrology 7(2): 815-827. doi:10.1002/eco.1405

Sayama T, Mcdonnell JJ, Dhakal A, Sullivan K. 2011. How much water can a watershed store? Hydrological Processes 3899-3908. doi:10.1002/hyp.8288

Scott RL, Cable WL, Huxman TE, Nagler PL, Hernandez M, Goodrich DC. 2008. Multiyear riparian evapotranspiration and groundwater use for a semiarid watershed. Journal of Arid Environments 72: 12321246. doi:10.1016/j.jaridenv.2008.01.001

Tague CL. 2009. Assessing climate change impacts on alpine streamflow and vegetation water use: Mining the linkages with subsurface hydrologic processes. Hydrological Processes 23(12): 1815-1819. doi:10.1002/hyp.7288

Thompson SE, Harman CJ, Troch PA, Brooks PD, Sivapalan M. 2011a. Spatial scale dependence of ecohydrologically mediated water balance partitioning: A synthesis framework for catchment ecohydrology. Water Resources Research 47: W00J03. doi:10.1029/2010WR009998

Thompson SE, Harman CJ, Konings AG, Sivapalan M, Neal A, Troch PA. 2011b. Comparative hydrology across AmeriFlux sites: The variable roles of climate, vegetation, and groundwater. Water Resources Research 47: W00J07. doi:10.1029/2010WR009797

Troch PA, Martinez GF, Pauwels VRN, Durcik M, Sivapalan M, Harman C, Brooks PD, Gupta H, Huxman T. 2009. Climate and vegetation water use efficiency at catchment scales. Hydrological Processes 23, 2409-2414. doi:10.1002/hyp 
Voepel H, Ruddell B, Schumer R, Troch PA, Brooks PD, Neal A, Durcik M, Sivapalan M. 2011. Quantifying the role of climate and landscape characteristics on hydrologic partitioning and vegetation response. Water Resources Research 47, 1-13. doi:10.1029/2010WR009944

Wang D, Wu L. 2013. Similarity of climate control on base flow and perennial stream density in the Budyko framework. Hydrology and Earth Systems Sciences 17: 315-332 


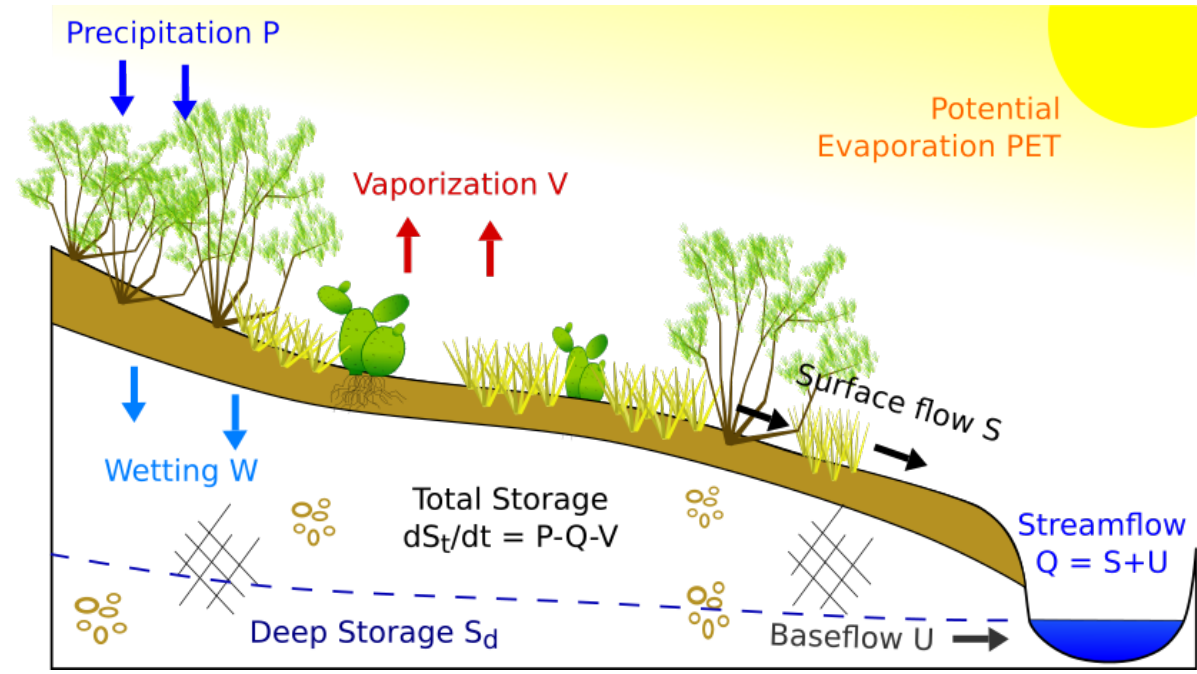

Figure 1. Conceptual model of hydrological water balance partitioning at the land surface in dryland environments. 


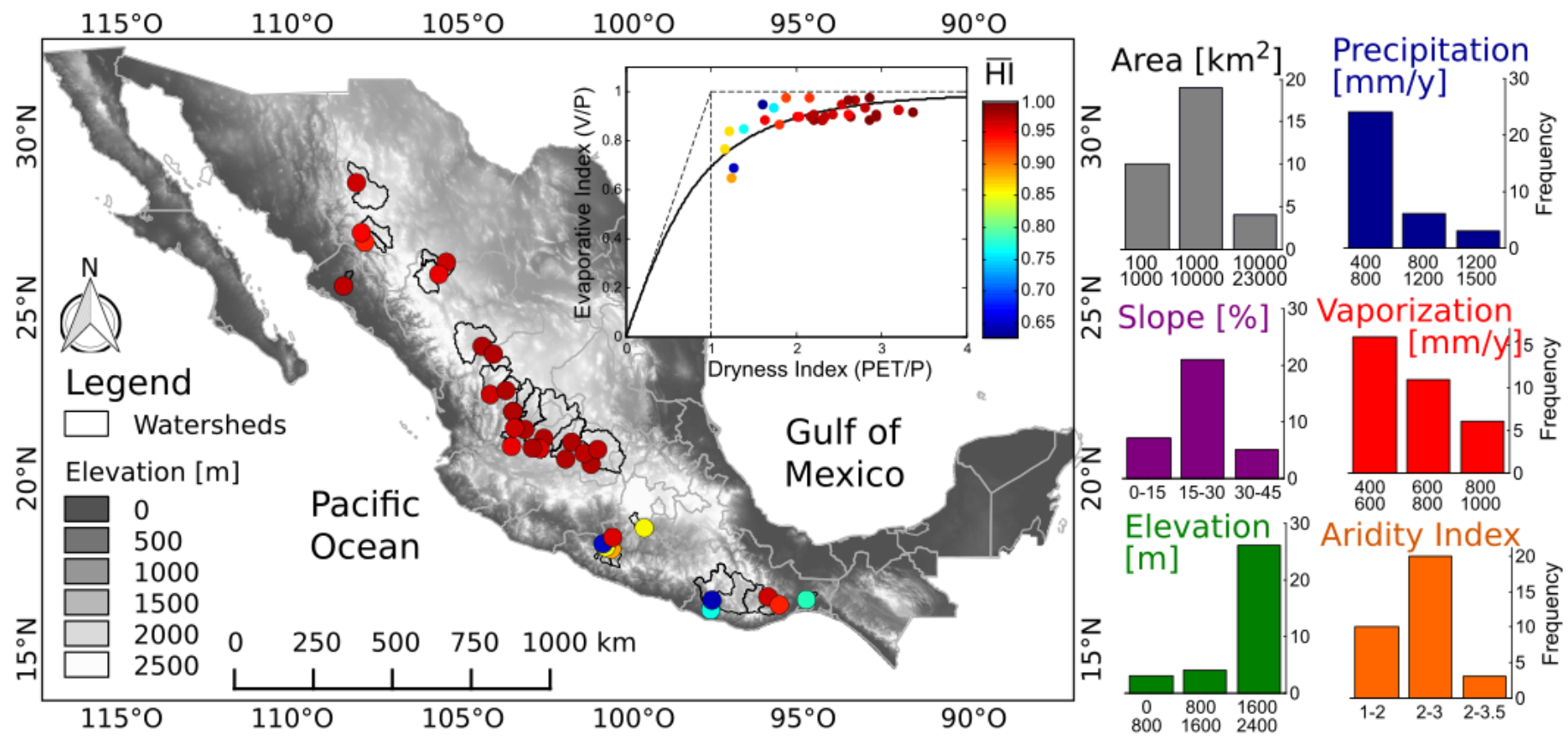

Figure 2. Map showing the study sites located in Mexico's drylands and displaying streamflow gauges (circles) and the mean annual Horton Index (color of the circle). Histograms of some important catchment properties (drainage areas, slope, elevation, precipitation, vaporization and aridity index) are shown at the right panels. 


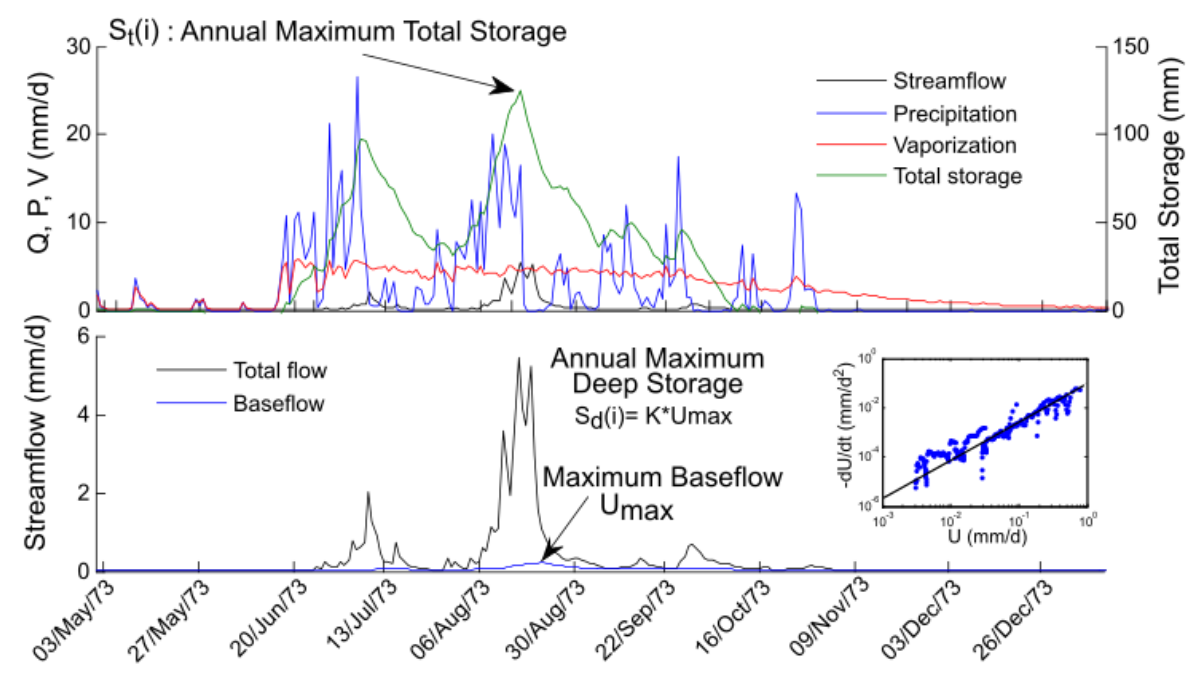

Figure 3. Temporal variation of water balance partitioning and streamflow at "El Tecomate" catchment during the rain season of 1973. Annual maximum total storage is extracted directly from the water balance and annual maximum deep storage is computed as the product between annual peak baseflow $\left(\mathrm{U}_{\max }\right)$ and storage constant $(\mathrm{K})$. 


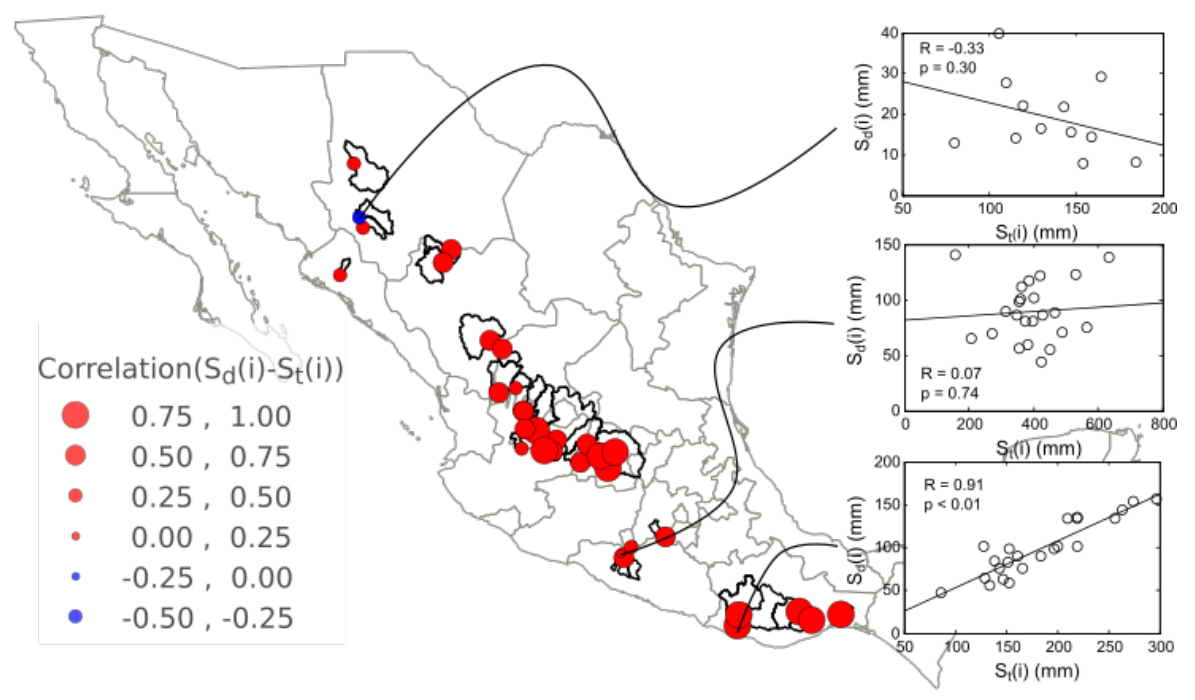

Figure 4. Map of the long-term Pearson correlation coefficients (R) between total, $S_{t}(i)$, and deep, $S_{d}(i)$, storage. Scatter plots show examples of catchment with high (larger red circles) and low (small red circles) statistical correlation. Blue circle (negative R) denotes a possible outlier. 

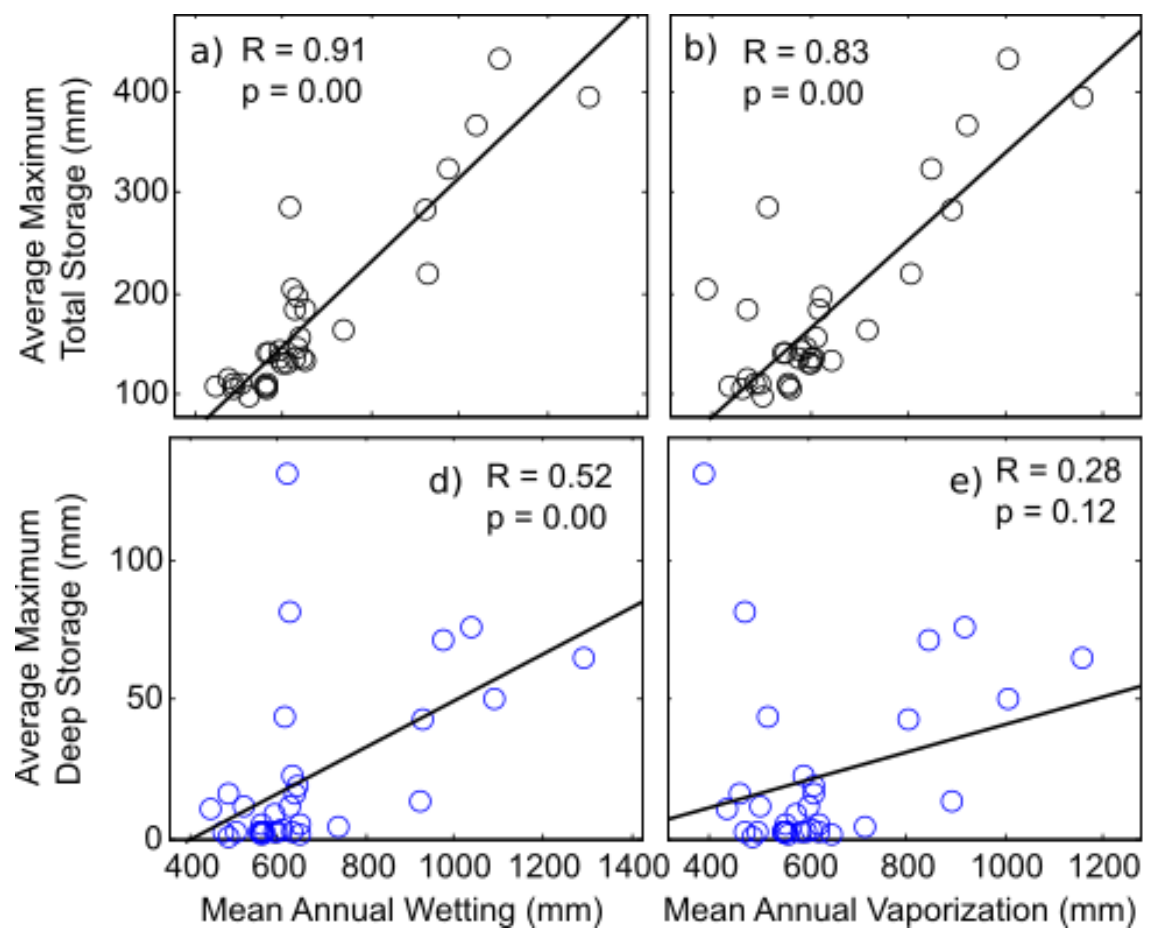
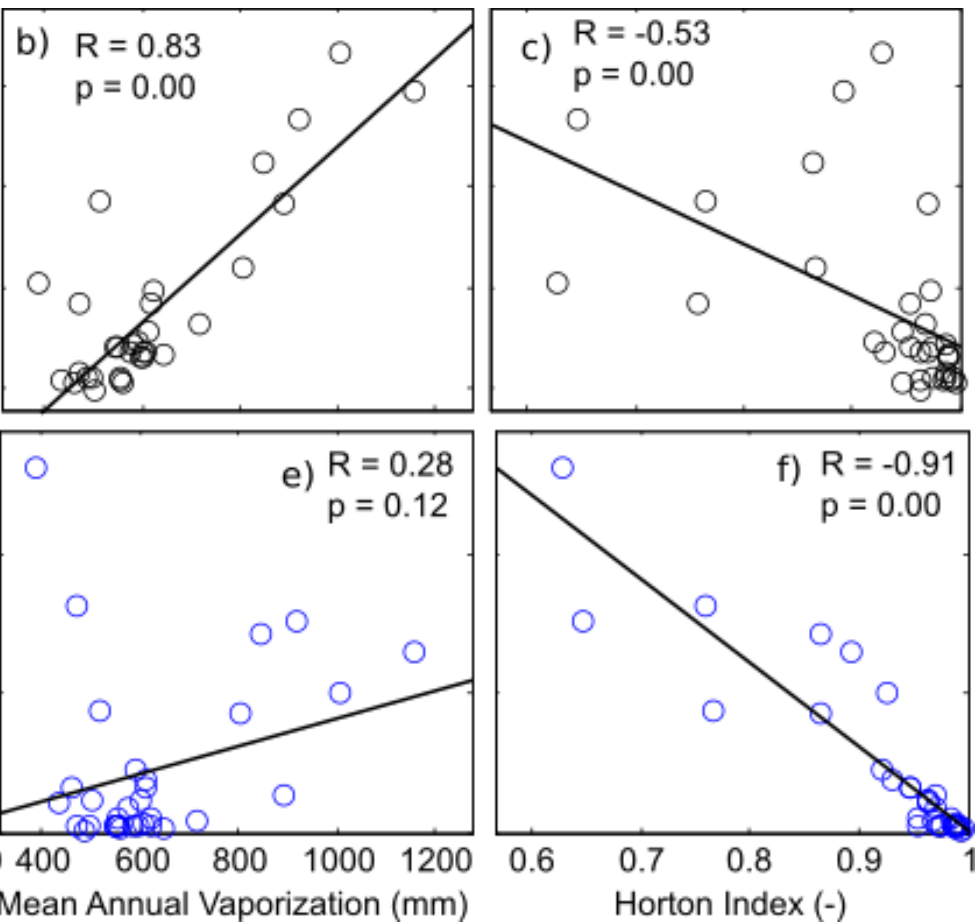

Figure 5. Long-term $\mathrm{W}, \mathrm{V}$ and $\mathrm{HI}$ controls on average maximum catchment-scale $\overline{S_{t}}$ (black) and $\overline{S_{d}}$ (blue). 


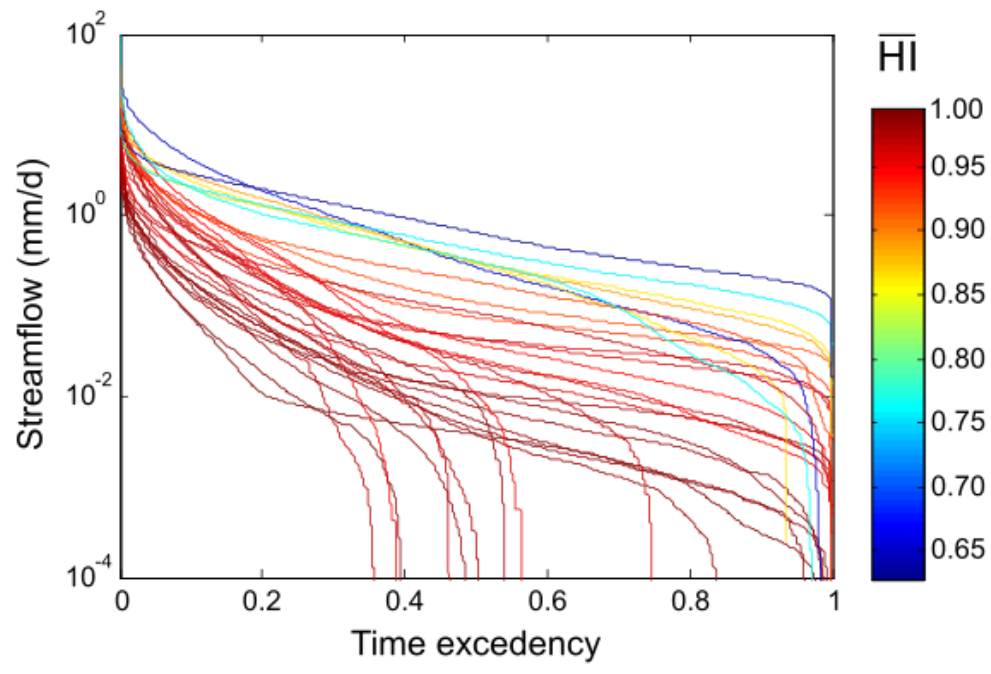

Figure 6. Flow duration curves for the 33 catchments, classified by their Horton Index. 
SUPPLEMENTARY MATERIAL 
Table S1. Main landscape (area, elevation, slope), climate (P, SIP, SIE, AI), water use efficiency (HI) and storage $\left(\overline{S_{t}}, \overline{S_{d}}\right)$ properties by catchment. Correlation coefficients $(\mathrm{R})$ and statistical significance (P_values) between $\overline{S_{t}}$ and $\overline{S_{d}}$ Catchments are sorted from the north to south and the first horizontal division on the table correspond to the catchment on the Sierra Madre Occidental, second division to the Altiplano catchments, and final part to the Sierra Madre del Sur catchments.

\begin{tabular}{|c|c|c|c|c|c|c|c|c|c|c|c|c|c|c|c|}
\hline Code & Period & Area & z & Slope & $\mathbf{P}$ & v & w & SIP & SIE & Al & HI & $\overline{S_{t}}$ & $\overline{S_{d}}$ & $\mathbf{R}$ & P_value \\
\hline 9011 & 83 & 96.54 & 10.80 & 0 & 58.4 & 2.4 & כ & 5 & 4 & 53 & 33 & 97.5 & 1.7 & .47 & 01 \\
\hline 10100 & $78-1994$ & 25.54 & 2190.28 & .60 & 40.1 & 0.0 & 3.8 & 1 & 49 & 15 & 0.930 & 134.3 & 8.8 & 0.33 & .30 \\
\hline 63 & 9 & 2220.05 & 9 & n & 7 & 7 & 5 & 0.77 & 4 & 87 & 22 & 5.5 & 2.5 & 5 & .23 \\
\hline 24195 & $1950-1974$ & 年 & (2) & 皮 &. & . & 446.2 & 0.89 & 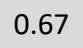 & 9 & כ & 5.7 & 5 & \pm & s \\
\hline 36071 & 1970 & 63.12 & 2295.79 & 0 & 1 & 6 & 4 & 0.84 & 3 & 2.61 & 18 & 03.7 & 5.9 & 1 & 1 \\
\hline 10034 & $1950-1986$ & 668.31 & 0 & 16.01 & 9 & 2 & 6 & 95 & 0.60 & 2.68 & 0.974 & .5 & 2.2 & 45 & 0.01 \\
\hline 11027 & $1963-1986$ & 0078.19 & 2185.69 & 14.20 & 478.7 & 469.1 & 475.0 & .91 & 0.68 & 2.61 & 0.987 & 113.8 & 2.7 & .65 & 0.00 \\
\hline 11040 & 006 & 7642 & 294.39 & .60 & 503.5 & 4 & 1 & 0.90 & 7 & 85 & 0995 & 1110 & 05 & 3 & 0.00 \\
\hline 12 & 1954-1991 & 1941.08 & 2256.24 & 17.00 & 607.1 & 595.1 & 599.7 & 0.00 & 0.64 & 3 & 0.990 & 1 & 2.4 & ك & 4 \\
\hline 12484 & 1955-1995 & 6336.52 & 2150.46 & 24.60 & 628.2 & 576.3 & 591 & 0.90 & 0. & 2.81 & 0.971 & 134.8 & 8.7 & 0.51 & 0.00 \\
\hline 1248 & 9 & 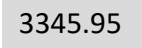 & 2 & 1 & 5 & 5 & 5 & 0.90 & 1 & 37 & 1 & 2 & 2 & 6 & 0 \\
\hline 5 & 2 & 2750.78 & 1996.17 & 15.80 & 666.5 & 602.5 & 623.8 & 0.95 & 0.73 & 2 & 3 & 4 & 2 & 0.63 & 0 \\
\hline 12540 & 961 & 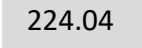 & 2246.47 & 5 & 7000 & 716.6 & 734.1 & 0.89 & 0.63 & 2 & 69 & 163.2 & 4. & 0.63 & .00 \\
\hline 12405 & 1966-1992 & 164.09 & 2045.62 & 18.80 & 610.5 & 604.5 & 610.9 & 0.9 & 0.7 & 2.93 & 0.990 & 131.1 & 3.6 & 0.90 & 0.00 \\
\hline 12370 & $1950-2004$ & 401.73 & 2115.84 & 8.30 & 578.0 & 554.6 & 560.1 & 089 & 0.73 & 2.64 & 0.988 & 110.5 & 1. & 0.7 & 0.00 \\
\hline 12418 & $60-1977$ & 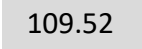 & 2089.49 & 16.00 & 601.7 & 58 & 5 & 0.89 & 0 & 2.20 & 0 & 1 & 2.4 & 0.68 & 000 \\
\hline 124 & 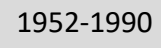 & 906.97 & 1 & 2 & 762.0 & 612.6 & 639.5 & 1.00 & 0.72 & 2 & 7 & 155.8 & 16.1 & 0.48 & 0.00 \\
\hline 12504 & $1950-1982$ & 022.99 & 2061.16 & 8.60 & 577.3 & 555.5 & 563.1 & .89 & 0.72 & 2.93 & 0.985 & 106.4 & 5.4 & .85 & 0.00 \\
\hline 12371 & 1950-1987 & 339.29 & 2024.23 & 3.40 & 685.9 & 548.8 & 570.0 & 0.99 & 0.75 & 2.00 & 0.953 & 140.2 & 2.6 & 0.74 & 0.00 \\
\hline 12535 & 1961-1984 & 17.09 & 2179.94 & 17.90 & 585.8 & 495.8 & 505.4 & 8 & 0.69 & 2.20 & 0.975 & 110.1 & 2.2 & 08 & 000 \\
\hline 12436 & 958-1978 & 525 & 2137.96 & 160 & 6278 & 5175 & 5623 & 0.85 & $06-2$ & 2. & 00 & 70 & 2 & 0.76 & > \\
\hline 12 & 3 & 2008.58 & 1925.54 & 0 & 654.6 & & 652.1 & 0.92 & 0.71 & 2 & 9 & כ & & & 0.00 \\
\hline 12238 & $1950-1980$ & 12093.95 & 2082.63 & 10.20 & 547.8 & 559.4 & 561.4 & 0.80 & 0.66 & 2.86 & 0.996 & 103.7 & 0.9 & 0.76 & 0.00 \\
\hline 18555 & 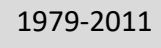 & . & ses & 0 & 2 & $8-2 \div$ & 924.8 & - 70 & 0.39 & 1 & 6 & 5 & 43.4 & 0.53 & 11 \\
\hline 104 & 67-1999 & (1) & (5. & . & . & 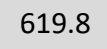 & . & 005 & 0.66 & 1.63 & 0.955 & 83.1 & 7 & 0.39 & 0.04 \\
\hline 18371 & 1965-1991 & קחת & 1376.46 & 45.40 & 10500 & 920.0 & 1037.8 & דת: & 0.38 & 1.26 & 0.647 & 366.0 & 76.7 & 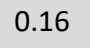 & 0.48 \\
\hline 18350 & 1964-1993 & 1059.90 & 1541.92 & 42.20 & 1169.2 & 847.6 & 973.8 & 0.88 & 0.40 & 1.16 & 0.864 & 323.6 & 71.5 & .64 & 0.00 \\
\hline 18277 & $1958-1981$ & 1538.83 & 1498.53 & 43.60 & 1493.2 & 1159.2 & 1293.6 & 0.85 & 0.38 & 1.24 & 0.892 & 395.5 & 5.4 & 0.07 & 0.74 \\
\hline 22008 & 950-1989 & (167797 & 1601.93 & 5 & 726 & 8928 & 0214 & 0.87 & 0 & 2.31 & 970 & 82.1 & 13.7 & 0.81 & 0.00 \\
\hline 22016 & $1950-1980$ & 429.44 & 528.42 & 29.90 & 930.3 & 515.2 & 612.0 & רחת & 0.52 & 1.38 & 0.766 & 285.6 & 44.3 & 0.78 & 0.00 \\
\hline 20021 & 1961-1991 & 7796.50 & 1832.45 & 33.10 & 807.5 & 390.0 & 620.3 & 0.88 & 0.55 & 1.60 & 0.628 & 203.9 & 132.0 & 0.79 & 0.00 \\
\hline 22015 & $1950-1975$ & 2261.49 & 1183.12 & 37.70 & 1205.0 & 1007.7 & 1088.1 & 0.8 & 0.33 & 1.80 & 0.927 & 434.6 & 50.8 & 0.82 & 0.00 \\
\hline 20017 & 1961-1985 & 17249.79 & 1734.44 & 30.90 & 766.1 & 471.6 & 623.6 & 0.89 & 0.57 & 1.73 & 0.758 & 184.1 & 82.1 & 0.91 & 0.00 \\
\hline
\end{tabular}

Period is the period of analysis for each catchment; Area is the catchment area in squared kilometers; $\mathrm{Z}$ is the catchment mean elevation, in meters; Slope is the catchment mean slope, in percent; $\mathrm{P}$ is the mean annual precipitation, in millimeters; $\mathrm{V}$ is the mean annual vaporization (evapotranspiration), in millimeters; 
$\mathrm{W}$ is the mean annual wetting, in millimeters; SIP is the precipitation seasonal index; SIE is the evapotranspiration seasonal index; $\mathrm{AI}$ is the aridity index; $\mathrm{HI}$ is the Horton index; $\overline{S_{t}}$ is the mean annual maximum total storage, in millimeters; $\overline{S_{d}}$ is the mean annual maximum deep storage, in millimeters; $\mathrm{R}$ is the linear correlation coefficient between $\overline{S_{t}}$ and $\overline{S_{d}}$; P_value is the significance of the correlation between $\overline{S_{t}}$ and $\overline{S_{d}}$, where bold values are not significant. 